\title{
ТРУДНОЩІ І ПОМИЛКИ ДИФЕРЕНЦІЙНОЇ ДІАГНОСТИКИ ПРИ ТУБЕРКУЛЬОЗНОМУ МЕНІНГОЕНЦЕФАЛІТІ У ДИТИНИ 6,5 МІСЯЦІВ
}

\author{
Львівський національний медичний університет ім. Данила Галицького
}

\begin{abstract}
У контексті дифреренційної діагностики гострих інфекційних уражень центральної нервової системи (ЦНС) проаналізовано випадок туберкульозного менінгоенцефаліту у дитини першого року життя на всіх етапах його розвитку - від туберкульозу легень до генералізованоі форми з ураженням ЦНС та причини, що призвели до пізньої (постмортальної) діагностики даного захворювання.

Ключові слова: гострі нейроінфекції, діти, епідеміологічний анамнез, туберкульоз, менінгоенцефаліт, клінічна і лабораторна діагностика.
\end{abstract}

Впродовж багатьох років проблеми гострих нейроінфекцій (ГНІ) у дітей не перестають бути актуальними у практичній медицині.

Клінічна діагностика ГНІ у дітей раннього віку, зокрема першого року життя, є найскладнішою серед усіх вікових груп. Слід зазначити, що у цій віковій групі в етіологічному спектрі ГНІ домінують бактерійні чинники, і процес ураження ЦНС нерідко має вторинний характер з розвитком найтяжчих клінічних фрорм, небезпечних щодо летальності або ж інвалідизації. Це стосується і туберкульозу, захворюваність на який залишається високою впродовж останніх двох десятиліть [1-3]. На жаль, клінічні прояви таких уражень не $€$ специфрічними стосовно етіології захворювання. Тільки на підставі сукупності клінічних, результатів додаткових параклінічних досліджень та даних епідеміологічного анамнезу вдається 3'ясувати етіологічний чинник і призначити адекватну етіотропну терапію. У випадку пізньої діагностики і, відповідно, пізнього призначення етіотропної терапії пацієнти найчастіше приречені на розвиток ускладнень, які можуть призвести навіть до летального завершення хвороби. Так, згідно з даними обласного патологоанатомічного бюро, за період 2005-2015 рр. у Львівській області від туберкульозного менінгоенцефаліту померло 10 дітей (1 летальний випадок в рік).

Мета роботи - з'ясувати об'єктивні і суб'єктивні обставини, що призвели до летального завершення хвороби у дитини 6,5 міс., хворої на туберкульозний менінгоенцефаліт.
На підставі даних карти амбулаторно-поліклінічного спостереження та карти стаціонарного хворого проаналізовано летальний випадок захворювання на генералізовану форму туберкульозу у дитини першого року життя.

Дитина Г., 6,5 міс. знаходилась на стаціонарному лікуванні в обласній інфекційній лікарні з 11.05 до 22.05.2014 p. з діагнозом: гострий менінгоенцефраліт, пухлина головного мозку?, церебральна кома III cm., поліорганна недостатність.

Зі слів матері, епідеміологічний та сімейний анамнез не обтяжені. Інші діти в сім'ї здорові.

З анамнезу життя відомо, що дитина народжена від III доношеної (40 тиж.) вагітності, III пологів (дані фр. 112). Оцінка за шкалою Апгар - 8 балів. Отримала вакцинацію BCG та проти ВГ. Через місяць після BCG-вакцинації на Iї місці з'явилась папула, яка в динаміці перетворилась у пустулу і в такому стані утримувалась до початку захворювання. Інші щеплення з невідомих причин не проводились.

3 анамнезу хвороби відомо, що дитина захворіла у віці 5 міс., коли на фроні нормальної температури тіла з'явився кашель. Дільничний лікар діагностував ГРЗ і амбулаторно призначив лікування амброксолом. Однак мати відмічала постійний сухий кашель і продовжувала лікувати дитину відхаркувальними засобами. Через місяць від початку захворювання у дитини до гіпертермічного рівня підвищилась температура тіла і виникли генералізовані тоніко-клонічні конвульсії. Госпіталізована у соматичне відділення. 3 діагностичною і лікувальною метою було зроблено люмбальну пункцію (ЛП). Ліквор, який витікав під дещо підвищеним тиском, виявився інтактним. За даними загального аналізу крові, на цей час спостерігались анемія та помірний нейтрофрільний лейкоцитоз. Враховуючи тяжкість стану, виразні неврологічні зміни (розлади свідомості, лівобічний геміпарез, який залишився після перенесених конвульсій), а також результати параклінічних тестів, з метою діагностики проведено МРТ головного мозку. Виявлені зміни трактувались як запальний процес. Тому, після консультації дитячим інфекціоністом, дитину 
переведено в обласну інфрекційну клінічну лікарню (ОІКЛ) з діагнозом гострий вірусний енцефраліт нез'ясованої етіології, судомний синдром, лівобічний геміпарез.

Бактеріоскопія та посіви ліквору, взятого під час першої ЛП у соматичному стаціонарі, були безрезультатними. Зміни, виявлені у динаміці, а саме: низький плеоцитоз змішаного характеру (70 клітин: нейтрофрільні гранулоцити - 53 \%, лімфочити - $47 \%$ ), підвищений рівень білка до 0,66 г/л при нормальному рівні цукру і хлоридів, на думку лікуючого лікаря, корелювали із результатом загального аналізу крові (Hb 95 г/л; L 3,8×1091/л, е. 2 \%, п. 21 \%, c. 41 \%, л. 32 \%, м. 4 \%; ШОЕ 4 мм/год) і були трактовані як зміни вірусного походження. Також за даними об'єктивного обстеження у дитини запідозрено пневмонію, підтверджену рентгенологічно. Враховуючи прогресуюче погіршення загального стану і неврологічного статусу, з метою подальшого обстеження і лікування дитина переведена у неврологічне відділення. їй було проведено електроенцефралографрію, типових вогнищ епілептичної активності не зареєстровано, діагностовано симптоматичну епілепсію на фроні вірусного енцефраліту. На цей час у хворої спостерігалась груба пірамідна недостатність у лівих кінцівках. Стан дитини погіршувався: знову виникла фебрильна гарячка, конвульсії, додалися анізокорія, девіація язика вправо, втрата свідомості та патологічне дихання по типу Чейна-Стокса з періодичними апное. Рентгенологічно виявлено негативну динаміку двобічної пневмонії.

У такому стані дитину повторно переведено в ОІКЛ, у відділення реанімації та інтенсивної терапії із діагнозом - судомний синдром, набряк-набухання головного мозку, церебральна кома. На чей час у лікворі нормалізувався плеоцитоз (11×1061/л), наросла білково-клітинна дисоціація. Білок у 10 разів перевищував верхню межу норми і становив 3,3 г/л. Як і при попередніх дослідженнях ліквору, рівень цукру утримувався в межах норми. Вірусологічні та серологічні дослідження дали негативні результати. Це дозволило думати про пухлину мозку. В зв'язку з неможливістю через тяжкість загального стану проведення контрольної МРТ головного мозку, зроблено нейросонографію (НСГ), при якій виявлено неоднорідність тканини головного мозку, розширення передніх рогів та III-го шлуночка.

Впродовж всього періоду перебування у відділенні інтенсивної терапії і реанімації дитині проводився комплекс заходів патогенетичної і посиндромної терапії. Неодноразово вона консультована вузькими спеціалістами - окулістом, неврологом, нейрохірургом, пульмонологом, рекомендації яких виконувались.

Враховуючи невизначеність етіології, дитина отримувала противірусну (зовіракс), а також антибактерійну (меронем) терапію. Незважаючи на лікування, позитивної динаміки у стані не спостерігалось. її стан прогресивно погіршувався і на 11-й день перебування в ОІКЛ дитина померла. Клінічний діагноз: гострий менінгоенцефраліт, пухлина головного мозку?, церебральна кома III cm., поліорганна недостатність.

Діагнози клінічний і патологоанатомічний не збігаються. У результаті патологоанатомічного дослідження було діагностовано: генералізований туберкульоз $з$ ураженням обох легень (множинні міліарні туберкульозні вузлики), паратрахеальних, біфруркаційних та мезентеріальних лімфатичних вузлів, селезінки, головного мозку та мозкових оболонок. Природжений некласифікований імунодефріцит: гіпотрофрія тимусу (маса до 5 г).

3 аналізу документації бачимо, що тривалість захворювання у дитини складала 6 тижнів. Впродовж всього часу домінуючим симптомом був сухий кашель. Незважаючи на стабільний кашель, про що зазначала мама, жодних додаткових досліджень на амбулаторному етапі не проводилось. Будь-які препарати етіотропної дії не призначались. Причиною госпіталізації послужило різке погіршення стану із розвитком тяжкої неврологічної симптоматики на фоні високої температури тіла. Клінічні прояви токсикозу зумовили припущення про інорекційну природу енцесралічної симптоматики, що, на думку медиків, підтверджувалось результатами дослідження ліквору та МРТ. Низький рівень змішаного плеоцитозу при помірному підвищенні білка та стабільно нормальному рівні цукру на початковому етапі стаціонарного лікування трактувався як прояв вірусної нейроінфекції. Однак динаміка лікворологічних досліджень (нормалізація плеоцитозу при значному підвищенні білка), результати МРТ і нейросонографії насторожили стосовно об'ємного процесу головного мозку. Зміни у легенях трактувались як банальна бактерійна пневмонія. На жаль, вже після смерті дитини, у наполегливій розмові з матір'ю з'ясувалось, що батько хворіє на туберкульоз легень. За інформацією фртизіатрів, у нього мультирезистентна фрорма захворювання і він продовжує лікуватись. Інформації про це дільничний лікар не отримав, а мати дитини замовчувала дані про захворювання батька, не усвідомлюючи епідеміологічної важливості та цінності даної інфрормації для встановлення діагнозу. Незважаючи на двобічне ураження легенів, на жодному з етапів стаціонарного лікування у лікарів не виникала думка про можливий туберкульоз. Імовірно, це пов'язано з тим, що дитина БЦЖ-вакцинована і в аналізі ліквору рівень глюкози в усіх дослідженнях утримувався в межах норми.

Аналізуючи ситуацію з захворюваністю на туберкульоз, можна стверджувати, що тривалий проміжок часу (80-90-ті роки минулого століття) завдяки організованій специфрічній профрілактиці туберкульозу та ефективному його лікуванню туберкульозний менінгіт не 3'являвся [4]. 
Тому настороженість щодо можливості захворювання на цю небезпечну хворобу знизилась. Як відомо, впродовж останніх двох десятиліть загострилась проблема туберкульозу не тільки в Україні і, зокрема, у Львівській області, а і в цілому світі [5]. Підвищення захворюваності призвело до збільшення кількості тяжких форм первинного туберкульозу і туберкульозного менінгіту у дітей. Відсутність у лікарів, навіть з великим стажем роботи, досвіду діагностики даного захворювання зумовлює гостру потребу нагадування про цю проблему. Особливо важливими є питання ранньої діагностики. Найбільш частою локалізацією туберкульозу ЦНС є туберкульозний менінгіт [6-9]. Він виникає внаслідок дисемінації бацили Коха (БК) гематогенним шляхом при первинному локальному вогнищі в легенях та прикореневих лімфровузлах, рідше в кишечнику і мезентеріальних лімсровузлах. Саме такі первинні локалізації і виявлено у померлої дитини. Місцем втілення інфекції внаслідок гематогенної дисемінації є відділи ЦНС з найбільш рясним кровопостачанням, де уповільнений кровообіг. Це сприяє осіданню БК. Такі капілярні мережі знаходяться передусім у м'якій і павутинній мозкових оболонках та у внутрішньому каналі мозкового стовбура.

Розвиток туберкульозного процесу в ЦНС залежить, насамперед, від ступеня пошкодження гематоенцефалічного бар'єру. Цьому сприяє багато різних фракторів, що спричинюють зниження неспецисрічного імунного захисту (активність клітин сполучної тканини, фрагоцитозу, захисної фрункції формених елементів крові). Також відомий вплив на організм соціально-побутових умов, харчування, частих попередніх захворювань, травм та багатьох інших факторів [2, 3].

Безсумнівне значення в порушенні гематоенцефалічного бар'єру у дітей раннього віку має його вікова незрілість і ступінь тяжкості первинного туберкульозу. Однак судинний бар'єр сплетінь все ж дуже стійкий і, здебільшого, зберігає свої фуункції, особливо якщо дисемінація невелика. Цим пояснюється той фракт, що у хворих на туберкульоз дітей відносно рідко виникає туберкульозний менінгіт [4]. Та навіть при незначному пошкодженні бар'єру в ліквор надходять БК і при переході їх в субарахноїдальний простір виникає ураження оболонок, переважно м'якої, з первинною локалізацією на основі мозку [9]. У м'якій мозковій оболонці виникає інфрільтрація з утворенням специфрічних для туберкульозу епітеліоїдних і гігантських клітин з вмістом у них БК. Одночасно з'являється ексудат різного типу: серозний, фрібринозний або змішаний. Буває і продуктивний процес з утворенням туберкульозних горбиків з казеозним розпадом. При туберкульозному процесі інфільтрується мозкова речовина навколо судин. У самій судині можуть виникати тромби, тому мозкова речовина страждає також від розладів живлення, що зумовлює розм'якшення відповідних ділянок мозку. Цим можна пояснити неоднорідність тканин, виявлену у хворого при НСГ обстеженні. При пізньому лікуванні або за його відсутності процес більш гостро і рано переходить з оболонок на виступаючі ділянки речовини основи мозку. Очевидно, саме такий патогенез розвитку захворювання спостерігався у померлої дитини. Зміни у цереброспінальній рідині набули характерних для об'ємного процесу ознак саме через розм'якшення ділянок речовини головного мозку, що визначалось результатами нейросонограсрії та МРТ.

Залишається відкритим питання про відсутність найбільш важливого дисреренційно-діагностичного критерію лабораторної діагностики при туберкульозі ЦНС, на який опираються практикуючі лікарі - зниження цукру у спинномозковій рідині. Сучасні джерела інформують, що зниження даного параметру характерне для всіх бактерійних менінгітів [10-13]. Проте нормальні показники цукру у лікворі абсолютно не виключають подібних діагнозів. До 50 \% хворих на бактерійний, у т.ч. туберкульозний, менінгіт можуть мати нормальний рівень цього показника $[10,12]$. Тому на сьогодні даний параметр не може служити абсолютним критерієм достовірності діагностики.

За даними сучасних джерел, зміни у лікворі при туберкульозному менінгіті мають доволі строкатий характер і можуть бути позбавлені класичних особливостей [5, 7]. У більшості хворих плеоцитоз має змішаний лімсроцитарнонейтрофільний характер. Це характерно для міліарного туберкульозу з обсіменінням мозкових оболонок. Характерною особливістю клітинного складу ліквору є наявність, поряд із великою кількістю лімфоцитів, нейтрофрільних гранулоцитів, моноцитів, макрофрагів та гігантських лімфоцитів. Треба зазначити, що трактування показників ліквору нерідко залежить від досвіду персоналу лабораторій. За даними окремих авторів, 10 \% мазків ліквору трактують неправильно, навіть у країнах з високим розвитком медицини [12]. Доцільно нагадати, що бактеріоскопічне дослідження ліквору проводять шляхом забарвлення мазків лікворного осаду за методом Грама. У зв'язку з кислотостійкістю мікобактерій туберкульозу виявити їх за допомогою такого методу неможливо. I тільки при підозрі стосовно туберкульозної етіології процесу мазок забарвлюють за методом Ціля-Нільсона.

Білок при туберкульозному менінгіті підвищується до 2-3 г/л ще до появи плеоцитозу. Але частіше такі зміни ліквору наводять на думку про об'ємний процес ЦНС. Слід зазначити, що при окремих фрормах туберкульозного менінгіту, який носить обмежений характер горбикового процесу у фразі фрібринозної інволюції і найчастіше локалізується в ділянці м'якої мозкової оболонки випуклої частини мозку і спаяної із відповідною зоною мозкової речовини, ліквор, як правило, залишається інтактним. Очевидно, саме в такій стадії розвитку патологічного процесу була проведена 


\section{КОРОТКІ ПОВІДОМЛЕННЯ}

перша люмбальна пункція нашій хворій. Треба зауважити що при інших бактерійних ураженнях ЦНС, зокрема, пневмококовому, також характерна виразна білково-клітинна дисоціація, при якій в лікворі випадає груба фрібринозна плівка. Процес утворення її залежить від зміни альбуміново/ глобулінового коефіцієнта на користь глобулінів (у нормі він складає 2:3 і вираховується за виразністю реакцій Панді і Нонне-Апельта). За даними досліджень ряду авторів, при туберкульозному менінгіті фрібринозна плівка утворюється лише у 65 \% хворих і має вигляд перевернутої ялинки [2, $5,7,8]$. Отже, її наявність або відсутність також не може бути критерієм абсолютного підтвердження чи заперечення захворювання на туберкульоз ЦНС.

Таким чином, проаналізувавши ймовірні патогенетичні процеси ураження ЦНС у даної дитини, став зрозумілим механізм патоморфологічних змін. Враховуючи ураження лімфратичних вузлів грудної клітки і черевної порожнини, хвороба дебютувала типово для туберкульозу. Характерний клінічний прояв первинного туберкульозу - настирний тривалий сухий кашель ігнорувався як ознака, при якій необхідне рентгенологічне обстеження органів грудної клітки, через відсутність настороженості щодо цієї небезпечної хвороби. Важливу роль при цьому відіграла відсутність даних про хворобу батька. Очевидно, що ніхто глибинно про сімейний анамнез із матір'ю не розмовляв і акцентів на туберкульоз не ставив. Інфікування на туберкульоз відбулося у перші дні від народження, коли імунітет проти туберкульозу, незважаючи на BCG-вакцинацію, ще не розвинувся. Тому інфрікування реалізувалось у розвиток генералізованої фрорми хвороби з ураженням ЦНС. У даної хворої не було найхарактерніших ознак туберкульозного ураження ЦНС: низького рівня цукру, виразного лімфоцитарного плеоцитозу. Тому динаміка лікворологічних змін з нормалізацією рівня плеоцитозу та значним підвищенням вмісту білка призвела до хибної підозри на об'ємний процес головного мозку. Однак, незважаючи на сказане вище, за наявності відомостей про туберкульоз у сім'ї, питання туберкульозу у дитини розглядалося б значно швидше як найбільш вірогідне.

\section{Висновки}

1. Структура менінгоенцефалітів у дітей поліетіологічна. Стабільне місце у ній належить збуднику туберкульозу.

2. Дані епідеміологічного анамнезу про контакт мають важливе значення у діагностиці туберкульозу. Тому лікарі, незалежно від клінічного профрілю, повинні цілеспрямовано опитувати пацієнтів про контакт з хворим на туберкульоз.

3. Несвоєчасна діагностика туберкульозу у дітей раннього віку та відсутність специфічного лікування призводять до генералізації патологічного процесу і летального завершення хвороби.

4. Особливістю сучасного перебігу туберкульозного менінгоенцефраліту у дітей є відсутність повного комплексу клінічних та параклінічних критеріїв, на які традиційно орієнтуються при діагностиці цього захворювання.

5. Повна або часткова відсутність комплексу основних критеріїв диктує необхідність популяризації відомих методів, зокрема ПЛР, і пошуку нових критеріїв діагностики туберкульозного менінгоенцесраліту у дітей.

6. Необхідно поліпшити координацію між протитуберкульозною службою та загальною медичною мережею для негайної поінорормованості дільничних лікарів про хворих на туберкульоз і проведення протиепідемічних заходів 3 метою зменшення ризику інфікування інших членів сім'ї, у тому числі дітей.

\section{Література}

1. Білогорцева O.І. Епідеміологічна ситуація щодо туберкульозу у дітей в Україні та шляхи удосконалення надання протитуберкульозної допомоги дітям / О.І. Білогорцева // Современная педиатрия. - 2014. - № 5 (61). - С. 22-26.

2. Фещенко Ю.І. Основи клінічної фтизіатрії: Керівництво для лікарів / Ю.І. Фещенко, В.М. Мельник, І.Г. Ільницький: В 2 т. - Київ; Львів: Атлас, 2007. - 1168 с.

3. Фещенко Ю.І. Туберкульоз, ВІЛ-інфекція та СНІД / Ю.І. Фещенко, В.М. Мельник, Л.В. Турченко. - К.: Здоров'я, 2004. $200 \mathrm{c}$.

4. Янченко Е.Н. Туберкулез у детей и подростков: Руководство для врачей / Е.Н. Янченко, М.С. Греймер. - СПб: Гиппократ, 1999. - 336 с

5. Панасюк О.В. Універсальний алгоритм діагностики туберкульозу різної локалізації / О.В. Панасюк, В.О. Панасюк, Г.В. Радиш // Укр. пульмонол. журн. - 2008. - № 3. - С. 65-69.

6. Діагностика туберкульозного менингита в современных условиях / [А.С. Ракишева, Ю.В. Репина, Г.Е. Тулепова та ін.] // Medicine. - 2014 - № 12. - C. 93-96.

7. Bartzatt R. Tuberculosis infections of the central nervous system / R. Bartzatt // Centr. Nerv. Syst. Agents Med. Chem. - 2011. - Vol. 11, N 4. - P. 321-327.

8. Справочник врача-сртизиатра / Под ред. Н.А. Шмелева и В.Л. Эйниса. - Москва: Гос. изд-во мед. литературы. - 1963. C. 1-77.

9. Пиккель М.В. Влияние фазы и течения общего туберкулеза на развитие и клиническую симптоматику туберкулезного менингита / М.В. Пиккель // Проблемы борьбы с туберкулезом в Архангельской области. - Л., 1970. - С. 93-98.

10. Relationship between cerebrospinal fluid glucose and serum glucose / L.E. Nigrovic, A.A. Kimia, S.S. Shah, M.I. Neuman // N. Engl. J. Med. - 2012. - Vol. 366, N 6. - P. 576-578.

11. Talan D.A. Bacterial cause of suspected meningitis cannot be safely excluded without cerebrospinal fluid analysis / D.A. Talan // Ann. Emerg. Med. - 2012. - Vol. 59, N 3. - P. 227-228.

12. Seehusen D.A. Analysis of cerebrospinal fluid / D.A. Seehusen, M.M. Reeves, D.A. Fomin // Am. Fam. Physician. - 2003. - Vol. 68. - P. 1103-1108.

13. Джафарова К.А. Сравнительная характеристика клиниколабораторных показателей и исходов бактериальных менингитов у детей разных возрастных групп / К.А. Джафарова, Ш.М. Рашидова, Ф.М. Раджабов // Современная педиатрия. - 2014. - № 4. - C. 31-34. 


\section{THE DIFFICULTIES AND MISTAKES IN THE DIFFERENTIAL DIAGNOSTICS OF TUBERCULOUS MENINGOENCEPHALITIS OF CHILD AGED 6,5 MONTHS}

M.B. Dasho, C.A. Lyshenyuk, U.B. Chulovska, H.O. Lytvyn

SUMMARY. In the context of differential diagnostics of acute infectious lesions of the CNS the case of tuberculous meningoencephalitis was analyzed in the child's first year of life at all stages of its development from the tuberculosis of lungs to a generalized form of the central nervous system (CNS) and the reasons that led to the late (posthumous) diagnostics of this disease. Key words: tuberculosis, children, acute neuroinfections, meningitis, encephalitis, clinic, diagnostics.

Отримано 18.03.2016 p.

DOI

\author{
М.А. Андрейчин
}

\title{
НАГОРОДНА МЕДАЛЬ ВСЕУКРАЇНСЬКОЇ АСОЦІАЦІЇ ІНФЕКЦІОНІСТІВ ДЛЯ МЕДИЧНИХ СЕСТЕР
}

Тернопільський державний медичний університет ім. І.Я. Горбачевського

Всеукраїнська асоціація інсрекціоністів (BAI) - громадська самоврядна організація, яка об'єднує на добровільних засадах лікарів-інфекціоністів. Вона була створена у травні 1997 року на установчих зборах в м. Полтава. Спочатку звалась Асоціацією інфекціоністів України. Перейменована на теперішню назву згідно з вимогою Закону України «Про громадські об'єднання» (2012р.).

За нашим поданням, 1 вересня 2015 року президія BAI прийняла «Положення про нагородження пам'ятною медаллю Святого Роха» медичних сестер інфекційних лікарень (відділень) і кабінетів інфрекційних захворювань поліклінік.

Рох належить до найбільш відомих і шанованих у християнському світі святих. Визнаний покровителем інсекційних хворих і захисником від епідемій. Свого часу (XIII ст.) він проявив надзвичайну жертовність і відвагу, працюючи на півдні Франції та в Італії в епідемічних осередках чуми. Надаючи допомогу хворим, сам заразився i, ймовірно, переніс бубонну фрорму чуми.

Згідно з «Положенням...», пам'ятною медаллю Святого Роха BAl нагороджує медичних сестер лікувальнопрофрілактичних закладів інфекційного профілю за милосердя та профресіоналізм, багаторічну сумлінну працю. Основні критерії відбору кандидата такі:
1. Обласний осередок (відокремлений підрозділ BAI) може пропонувати 1-2 кандидатури, м. Київ і область - 3.

2. Претендент повинен мати не менше 20 років професійного стажу роботи з інсрекційними хворими і бездоганну службову характеристику. Кандидатури мають пройти обговорення і затвердження шляхом голосування на засіданні обласного осередку.

3. Витяг з протоколу засідання осередку подається до президії BAI не пізніше, ніж за 10 днів до чергового з'їзду BAI із зазначенням прізвища, імені, по батькові, посади і місця роботи претендента.

4. Нагородженому або голові обласного осередку інфекціоністів (за відсутності нагородженої особи) медаль і посвідчення вручає президент BAI на найближчому з'їзді інсрекціоністів України.

5. Уповноважений голова обласного осередку зобов'язаний вручити нагородженій особі медаль і посвідчення в найближчий місяць на зібранні колективу.

Медаль створив львівський медальєр Богуслав Петрович Гриник, виготовило ТзОВ «Штука». Вона діаметром 51 мм, з латуні, покритої позолотою. Організаційні клопоти на себе взяв секретар BAІ доцент О.Л. Івахів.

У центрі аверсу цієї вишуканої медалі художник розмістив рельєфний, дещо повернутий вправо анфрас Роха 3 